\title{
Coelhos na cartola: publicidade e entretenimento na campanha de Sony Bravia
}

Juliana de Assis Furtado

\section{Resumo:}

Na publicidade contemporânea, observamos um movimento de certas campanhas para uma direção que exclui a racionalidade. O produto surge desmaterializado, caracterizado por sensações, sons e idéias visuais que, em conjunto, transmitem seu benefício de uma forma intangível. Em muitos casos, ele apenas assina a peça, aliado à força de um conceito que centraliza suas qualidades. O imperativo é ausente, e a persuasão fica por conta de uma imagem de marca pré-construída, que concentra valores invisíveis - mas já cravados no imaginário do público a que se destina. O lúdico toma conta da mensagem, tornando-se a ponte que separa (ou une) publicidade e entretenimento. É o caso da campanha publicitária da TV Sony Bravia, que há alguns anos tem seus filmes premiados em festivais pelo mundo. Neste trabalho, analisamos o mais recente deles, ouro em Cannes no ano de 2008. Como acontece a desmaterialização? Pelo que o produto é substituído? Que valores essa construção veicula? São perguntas que buscamos responder.

\section{Palavras Chave:}

Publicidade, entretenimento, consumo, espetáculo, marca.

\begin{abstract}
:
In contemporary advertising, we observed a movement of campaigns for a direction which excludes the rationality. The product is dematerialized, characterized by sensations, sounds and ideas that, together, transmit the benefit in an intangible way. In many cases, the product only signs the ad, combined with a strong concept that centralizes its qualities. The imperative is absent, and persuasion occurs by a pre-built brand image, which focuses invisible values - but that are in the imagination of the target. The ludic takes the post, becoming the bridge that separates (or connect) advertising and entertainment. This is the case of advertising campaign for Sony Bravia TV, that for few years ago had their films awarded in festivals around the world. In this study, we analyzed the most recent of them, gold in Cannes in the year 2008. How does it happen the dematerialisation? For what the product is replaced? Which values this construction transmit? These are questions that seek to answer.
\end{abstract}

\section{Keywords:}

Advertising, entertainment, consumption, spectacle, brand.

Na publicidade contemporânea, observamos um movimento de certas campanhas para uma direção que exclui a racionalidade. O produto surge desmaterializado, caracterizado por sensações, sons e idéias visuais que, em conjunto, transmitem seu benefício de uma forma intangível. Em muitos casos, ele apenas 
assina a peça, aliado à força de um conceito que centraliza suas qualidades. O imperativo é ausente, e a persuasão fica por conta de uma imagem de marca pré-construída, que concentra valores invisíveis - mas já cravados no imaginário do público a que se destina. O lúdico toma conta da mensagem, tornando-se a ponte que separa (ou une) publicidade e entretenimento.

É este o caso da campanha publicitária da linha de televisores de LCD Bravia, da Sony, que há alguns anos constata um grande sucesso nas vendas ao mesmo tempo em que tem seus filmes premiados em festivais pelo mundo. Neste trabalho, analisamos o mais recente deles, ouro em Cannes no ano de 2008. Qual a estratégia utilizada? Como acontece a desmaterialização? Pelo que o produto é substituído? Que valores essa construção veicula?

A campanha de Sony Bravia iniciou-se em 2005 com o filme Balls, que teve como alguns de seus resultados TVs esgotadas nas lojas e um leão de ouro em Cannes no ano seguinte. Bolas coloridas surgindo por todos os lados e tomando conta das ladeiras de São Francisco compunham o filme de produção impecável, em que Sony Bravia ocupava apenas os últimos segundos. $\mathrm{Na}$ assinatura, apenas o conceito Colour like no other, um desdobramento do slogan corporativo like.no.other, seguido da imagem do produto.

Por trás da complexa fachada da ilusão, o objetivo é muito simples: vender televisores. E se funciona, por que mudar a estratégia? A alta receptividade da publicidade se refletiu em alta no consumo, e a fórmula é repetida pela Sony em 2006, quando entrou no ar o filme Paint. Um milhão de visitas ao site do produto e ouro em Cannes 2007 foram alguns dos efeitos gerados pela peça. A surpresa não é tão intensa como no primeiro filme da série, mas causa estarrecimento semelhante pela complexidade de sua produção. Filmado na Escócia, Paint precisou de 70 mil litros de tinta, 322 morteiros, 330 metros de canos de aço e 57 quilômetros de fios de cobre para dar vida a explosões coloridas de proporções gigantescas. Para completar a trilogia, em 2007 foi ao ar Play-Doh (massa de modelar), que alimentou expectativas e promoveu discussões on-line desde o momento em que seu teaser foi divulgado pela empresa, e seria vencedor de mais um leão de ouro em Cannes 2008. Dessa vez, coelhos feitos de massinha se multiplicavam em uma velocidade crescente, inundando de cores as ruas de Manhattan.

A força desta campanha é auto-explicável, visto a aposta da empresa na sua continuidade e a resposta do mercado e do público. Mas o que tanto nos chama a atenção, motivando a elaboração desta análise? A abstração do benefício principal de Sony Bravia (a qualidade das cores, com alta definição), a ausência de apelo persuasivo direto e a mínima aparição do produto e da marca são o que nos faz parar para pensar sobre estas produções e observar mais de perto o filme Play-Doh. Percebemos aqui a presença do "espetáculo", já definido por Guy Debord, para quem

imagens tornam-se seres reais e motivações eficientes típicas de um comportamento hipnótico. O espetáculo, como tendência para "fazer ver" por diferentes mediações especializadas o mundo que já não é diretamente apreensível, encontra normalmente na visão o sentido humano privilegiado que noutras épocas foi o tato; a visão, o sentido mais abstrato, e o mais mistificável, corresponde à abstração generalizada da sociedade atual (DEBORD, 2002:18).

Imagens que hipnotizam, um espetáculo que não cessa, compõem a publicidade na sua vertente mais lúdica, a "publicidade-entretenimento". Num momento em que a abundância é a regra e marcas disputam mais do que nunca a atenção (e o dinheiro) do consumidor, há de se buscar formas de se destacar no meio do intervalo da programação, evitando a fuga da propaganda com um clique no controle remoto. E uma das chaves pode ser essa: fornecer, no intervalo, mais entretenimento. Vender: o que mais faria colocar um gorila tocando bateria ao som de Phil Collins, para nos segundos finais assinar uma marca de chocolates? Não é de se estranhar que a estratégia, idêntica à utilizada na trilogia de Bravia, tenha rendido 
uma espetacular mídia viral para a Cadbury. E não é coincidência que os quatro filmes tenham sido criados pelo mesmo publicitário, o argentino Juan Cabral. O caminho trilhado é o mesmo porque tem mostrado que funciona. Conforme Baudrillard em entrevista à revista Época, hoje "o objeto é o discurso, que promove intercâmbios virtuais incontroláveis, para além do objeto" (GIRON, 2003). É esse "além" que parece estar sendo explorado na publicidade contemporânea, mesmo que o preço a pagar seja deixar o próprio objeto em segundo plano. Isso é compensado por estratégias externas ligadas ao filme que reforçam a construção de uma marca sólida, que pode assim dispensar palavras para explicar seu valor e conquistar seu público.

A publicidade sempre foi um espetáculo, a partir do momento em que é uma "representação" do produto. Seria então a publicidade-entretenimento o espetáculo do espetáculo? É o que buscamos compreender.

\section{Cartola: Sociedade e publicidade contemporâneas}

Conforme Bauman (1999) na obra Globalização: as conseqüências humanas, nossa sociedade é uma sociedade de consumo, o que significa que é preciso engajar seus membros pela condição de consumidores. Nesta sociedade, a economia gira em torno da mercadoria, que reina soberana. Ela está por todos os lados, dos shopping centers à internet, das ruas às malas-diretas, num oferecer-se incessante. Como nos mostra Baudrillard (1991: 114), o modelo veicular da única grande e verdadeira idéia-força desta sociedade concorrencial é a mercadoria e a marca.

Configura-se a sociedade do espetáculo de Debord, na qual o grande comércio e a acumulação de capitais geraram uma abundância de mercadorias e o domínio da mercadoria sobre a economia. Segundo o autor, "o espetáculo é o momento em que a mercadoria chega à ocupação total da vida social. Tudo isso é perfeitamente visível com relação à mercadoria, pois nada mais se vê senão ela: o mundo visível é o seu mundo" (DEBORD, 2002: 30).

A publicidade é o meio pelo qual se deságua toda essa abundância de mercadorias produzidas. Como elemento cultural da sociedade espetacular, ela adquire mais do que nunca os contornos de um espetáculo, misturando cores, sons, ficção, sonho e (pouca) realidade, por meio dos quais desenvolve seus apelos sempre positivos, grandiosos, tentadores.

Vivemos em um momento de competitividade global. Para enfrentá-la "os bens, serviços, devem despertar desejo, e para isso, devem seduzir os possíveis consumidores e afastar competidores" (BAUMAN, 1999: 86). Isso é um trabalho incessante, visto que a satisfação nunca é plena - ou a lógica capitalista entraria em colapso. Na ditadura da obsolescência programada, há sempre algo melhor para se "querer", algo mais moderno para se "ter", algo mais apaixonante para "levar".

Ao mesmo tempo, contemplamos um mundo que se move. Não a cada década, nem a cada ano, mas a cada minuto. A mobilidade é a regra, como descreve Bauman:

A maioria está em movimento mesmo fisicamente parada - quando, como é hábito, estamos grudados na poltrona e passando na tela os canais de TV via satélite ou a cabo, saltando para dentro e para fora de espaços estrangeiros [...] , sem ficar em lugar algum tempo suficiente para ser mais do que visitantes, para nos sentirmos em casa (1999: 85).

Como ferramenta de venda dos bens produzidos, a publicidade precisa estar preparada para atender a um consumidor cada vez mais conectado, bem informado, difícil de ser convencido e ávido por novidades. "O jogo do consumidor não é acumular riqueza no sentido do palpável, mas a excitação de uma sensação nova, ainda não experimentada" (BAUMAN, 1999: 91). Ele não sossega enquanto não satisfizer seus 
desejos, mesmo que logo em seguida estes sejam substituídos por outros mais novos e sedutores.

Nesse contexto, o "marketing de interrupção" começa a ter menos êxito, como aponta Seth Godin: "nos velhos tempos, vendíamos um produto pelo marketing de interrupção. Publicávamos anúncios, interrompíamos as pessoas com anúncios imprevistos, impessoais e irrelevantes na esperança de que elas fossem comprar alguma coisa. E isso, às vezes, funcionava". Num momento em que o tempo livre se torna um bem - e escasso - disputar espaço com o lazer torna-se mais desafiador ainda. Fazer com que alguém fique sem mudar de canal quando seu programa preferido foi para o intervalo é quase uma façanha.

$\mathrm{Na}$ busca de promover as novas sensações que o consumidor procura e, além disso, viabilizar publicidade com custo menor e com longo alcance, têm surgido, nas últimas décadas, novas técnicas e formatos publicitários. Primeiro chegaram as mídias alternativas (publicidade em banheiros, bolachas de chope, elevadores e os mais inusitados locais por onde o consumidor pode passar e ser surpreendido). Mais recentemente, desenvolve-se o advertainment, junção de advertising com entertainment e que pode ser definido pela produção de conteúdo por uma marca, no lugar de apenas patrocinar conteúdos. Como descreve Nogueira (2004), a nova estratégia pode desenrolar-se na forma de conteúdos para TV (programas criados por anunciantes; programas sem intervalos comerciais); advergames (jogos com publicidade que podem ser baixados gratuitamente na internet); vídeos virais (vídeos em que o entretenimento tem o destaque e o produto aparece apenas em segundo plano, o que confere a eles grande potencial de difusão, como um vírus); vídeos interativos; mobile marketing (publicidade em celular, como ringtones gratuitos); publicidade subviral (contra-propaganda sobre uma marca que acaba se tornando viral, gerando buzz - ou "buxixo" - positivo sobre aquela marca). Além disso, também existe o product placement (parceria entre anunciante e programa/filme, que tem a vantagem de associar o produto ao clima dessa produção, com a possibilidade de ligar a marca a uma determinada personagem, com uma determinada personalidade, estilo de vida, atitude) (PRODUCT PLACEMENT, 2009).

Enquanto a mídia alternativa continua a interromper, como a publicidade tradicional, o advertaiment revela-se atualmente como uma proposta mais inteligente, capaz de envolver o público a que se destina de uma forma mais natural e ativa. Parece mais eficaz que a publicidade passe ao patamar da venda de sensações no lugar da venda de produtos, pois é isso que conquista o consumidor contemporâneo. A importância da "idéia" é cada vez maior, tanto para minimizar custos quanto para atrair atenções.

Aqui chegamos ao ponto central deste trabalho. Dentro do contexto descrito, junto a essas mudanças e apesar delas, a publicidade tradicional continua a existir. Ela ainda está na TV, está nas revistas, nas rádios, nos outdoors (nas cidades em que a Lei Cidade Limpa ainda não chegou) e em todos os meios de comunicação de massa que existem há tempos. Nas palavras de José Bonifácio de Oliveira Sobrinho, o Boni - por três décadas o principal executivo da Rede Globo, tendo trabalhado ao lado do fundador Roberto Marinho - "muitos já preferem outros meios mais interativos, como a web [...] e com certeza deve haver uma concorrência no futuro. Mas a televisão continuará a ser o centro. Principalmente porque as telas estão aumentando de tamanho. Quando você vai assistir a um programa, prefere ver em uma telinha do PC ou em uma telona na sala? A televisão vai continuar aí por muito tempo ainda" (TELEVISÃO, 2009). A tese de Boni pode ser reforçada com a chegada da TV digital, e a decorrente melhoria de som e imagem, oferta de mais canais, interatividade e possibilidade de gravação de programas. A publicidade televisiva nos moldes tradicionais não foi extinta, e mesmo em tempos de crise e com a diminuição de investimentos, continua a fazer circular milhões. A nova preocupação é, porém, maximizar os efeitos desses investimentos, o que exige certos cuidados e inovações na estratégia de lançamento de uma campanha. Ainda há investimentos astronômicos, mas eles devem mais do que nunca gerar resultados positivos para a marca ou a empresa, ou não passariam de uma loucura. A mídia 
tradicional recebe então uma nova tarefa: se reinventar.

Uma das possibilidades para viabilizar essa reinvenção é a exploração do entretenimento, que pode ser incluído na publicidade tradicional. Uma boa idéia, somada a estratégias on-line que a fortalecem e minimizam os riscos de gastar milhões, pode resultar em um filme de TV que não passa despercebido, chama a atenção de inúmeros consumidores potenciais e gera resultados fortalecedores para a marca. Como exemplo disso, veremos a seguir como a Sony trabalhou sua estratégia publicitária para a TV de LCD Sony Bravia. Observaremos as ferramentas usadas, bem como os efeitos que ela teve sobre o público.

\section{Coelhos: a estratégia de Sony Bravia}

2,5 toneladas de massa de modelar, 189 coelhos, 150 cubos, 1 coelho gigante, 40 animadores para a cada 4 horas gerar 4 segundos de película. Após três semanas de filmagem e um cuidadoso trabalho de montagem e finalização, tomava forma um filme de 1 minuto e meio, mais um investimento de grande porte da Sony que viria ao ar em outubro de 2007.

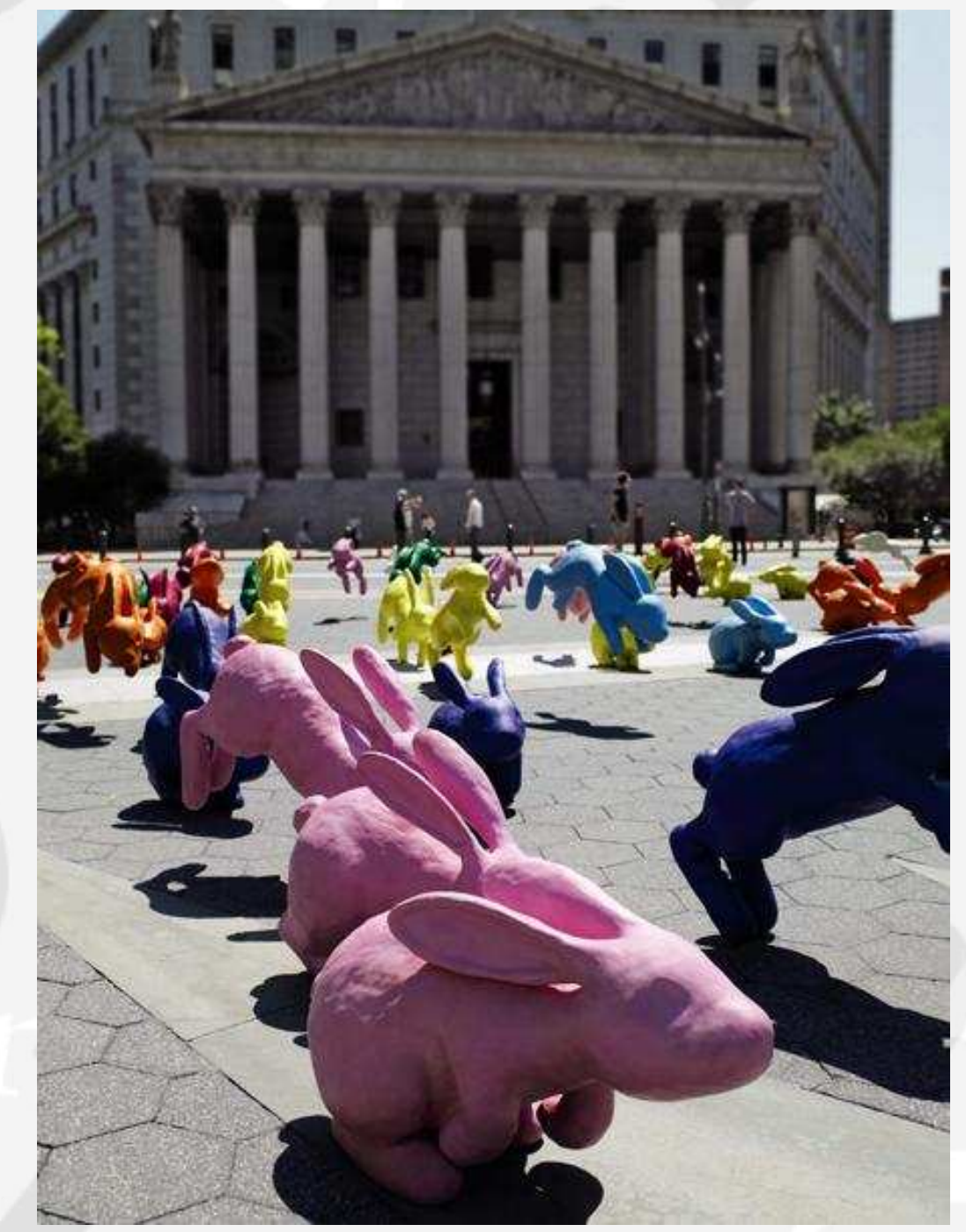

Figura 1: Cena do filme Play-Doh. Fonte: Site Photobucket, 2009. 
Como comentamos, Play-Doh completa a trilogia de filmes publicitários criados para Sony Bravia pela sua agência londrina da Sony, a Fallon. Por meio da técnica stop-motion, em que milhares de fotografias são colocadas em seqüência dando movimento à cena, coelhos feitos de massinha das mais variadas cores invadem a cidade de Nova Iorque, saindo de canos, latas de lixo, bueiros, correndo pelas calçadas e praças públicas. Cruzam o trânsito caótico e, unidos, transformam-se em uma onda gigantesca que quebra no chão. A onda, então, desdobra-se em blocos de gelo, de onde surge uma baleia vermelha. Ela mergulha no chão até que sua cauda, saindo do "mar", metamorfoseia-se em um enorme coelho, que por sua vez afunda no chão dando origem a cubos multicoloridos. Enquanto tudo acontece, estupefatos, passantes admiram a multiplicação e a metamorfose, sejam idosos, adultos ou crianças.

Um locutor fala do que se trata? Nem uma palavra. No lugar dele, uma trilha sonora escolhida a dedo toca ao fundo. É She's a rainbow, dos Rolling Stones, que diz:

She comes in colors everywhere/ She combs her hair/ She's like a rainbow/ Coming colors in the air/ Oh, everywhere/ She comes in colors/ Have you seen her dressed in blue/ See the sky in front of you/ And her face is like a sail/ Speck of white so fair and pale/ Have you seen the lady fairer/ She comes in colors everywhere/ She combs her hair/ She's like a rainbow/ Coming colors in the air/ Oh, everywhere/ She comes in colors/ Have you seen her all in gold/ Like a queen in days of old/ She shoots colors all around/ Like a sunset going down/ Have you seen the lady fairer.

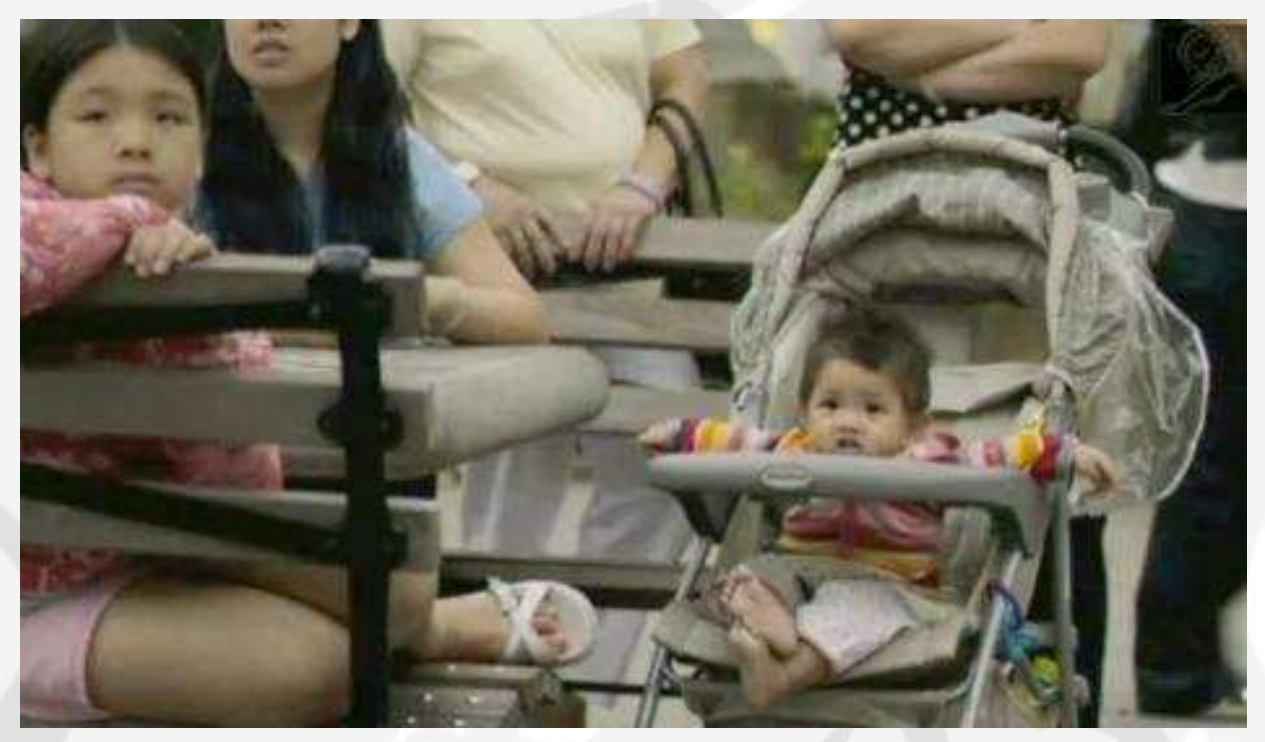

Figura 2: Cena do filme Play-Doh. Fonte: Site YouTube, 2009.

Cores infinitas, um verdadeiro arco-íris: é o que vemos e ouvimos durante um minuto e vinte segundos. Depois disso, sobram os dez segundos finais para a entrada da assinatura Colour like no other - sobre os cubos multicoloridos, que vemos rodar por vista aérea -, o produto (a TV de LCD) e o logotipo da marca (estes dois últimos apenas nos cinco segundos finais). A marca, porém, não está ausente durante o filme todo. Vestida de entretenimento, Sony Bravia aparece o tempo todo por meio de seu benefício intangível, a alta definição de imagem, que, por sua vez, é representada pelos coelhos. A partir deste benefício, é 
composto um espetáculo que toma conta da cidade e, ao mesmo tempo, da tela onde seu público assiste ao filme, estupefato como os nova-iorquinos que participaram da filmagem. "O mundo presente e ausente que o espetáculo faz ver é o mundo da mercadoria dominando tudo o que é vivido" (DEBORD, 2002: 28).

Como ficção, que não tem como objetivo mostrar o mundo exatamente como ele é, a publicidade pode trabalhar no nível do intangível, valorizando a vivência, a satisfação e o bem-estar. O entretenimento entra como ferramenta para realizar este projeto, evitando que a publicidade passe despercebida ou seja anulada por um simples clique no controle remoto. Meio milhão de pessoas parou para ver coelhos de massinha espalhando-se pela cidade, só na internet. Jogando com a curiosidade, com o lúdico e o inesperado, a publicidade envolve o consumidor que, desarmado, assiste o filme até o final, quando o produto entra para fazer o link. Podemos analisar esta estratégia por meio do mapa semiótico de Andrea Semprini, modelo de análise criado com base nos estudos de Floch.

\section{UTÓPICO}

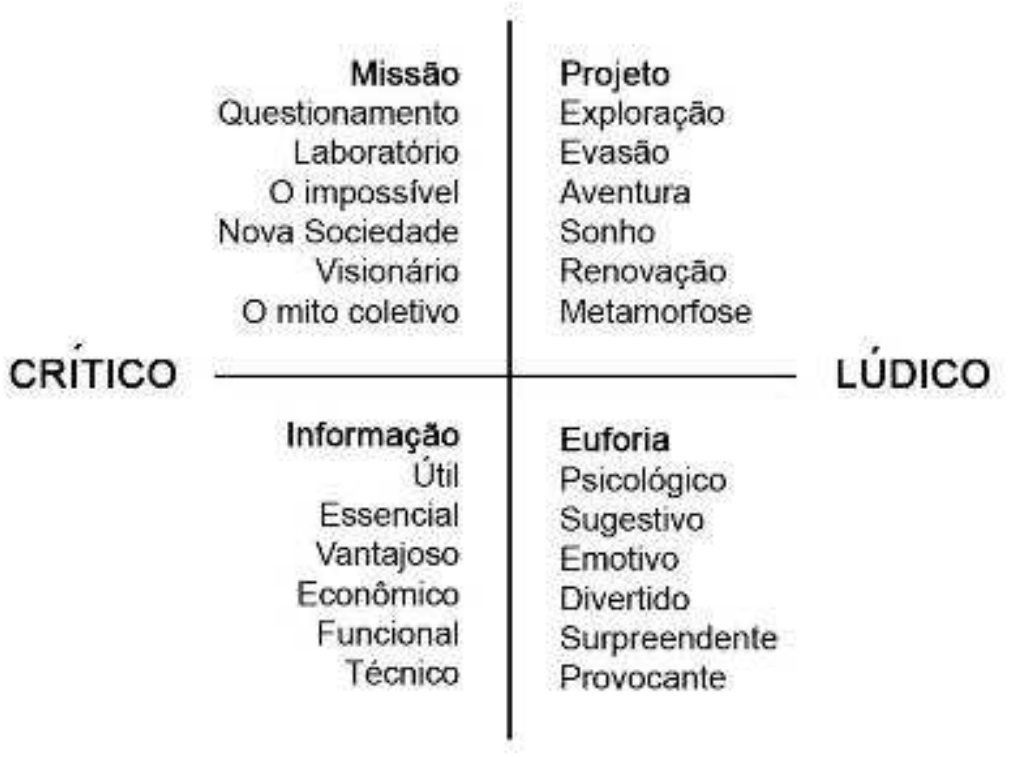

\section{PRÁTICO}

Figura 3: Mapa semiótico geral de Semprini.

Fonte: SOUZA; SANTARELLI, 2008.

$\mathrm{Na}$ obra Le marketing de la marque, partindo da tipologia estabelecida por Floch em J'aime, j'aime, j'aime..., o autor elaborou um mapa de análise da marca de acordo com valores de consumo. Nele, as marcas se posicionam em um quadrante em relação aos seus concorrentes e constroem uma imagem, que transparece na sua publicidade (SOUZA; SANTARELLI, 2008). Observando o quadro, podemos localizar o filme de Sony Bravia em dois quadrantes. Em primeiro lugar, no quadrante utópico-lúdico, já que o filme traça o caminho do sonho, representado pelos coelhos animados invadindo uma cidade real. Ao mesmo tempo e, principalmente, o filme localiza-se no quadrante lúdico-prático (ou da "euforia"), por apresentar muitas das suas características: ele mexe com o psicológico, com a emoção do público, é 
divertido, causa surpresa e provoca. Conforme comentamos, a reação das pessoas que participam do filme, que assistem atônitas ou sorridentes ao espetáculo da multiplicação, é semelhante à reação do público que vê o filme pela TV ou pela internet.

Nesse contexto, valores racionais como o "útil', o "econômico" e o "funcional", que compõem o quadrante crítico-prático de Semprini, não têm lugar. O próprio produto foi posicionado em segundo plano, ou, mais do que isso, desmaterializado. Não é ele quem aparece, mas o que ele proporciona. Ele, como objeto, quase não mais existe. O que existe é o valor da marca Sony, mais importante que a TV de LCD, dissociado dela e fortalecido no imaginário das pessoas. O produto não é mais corpo: é alma.

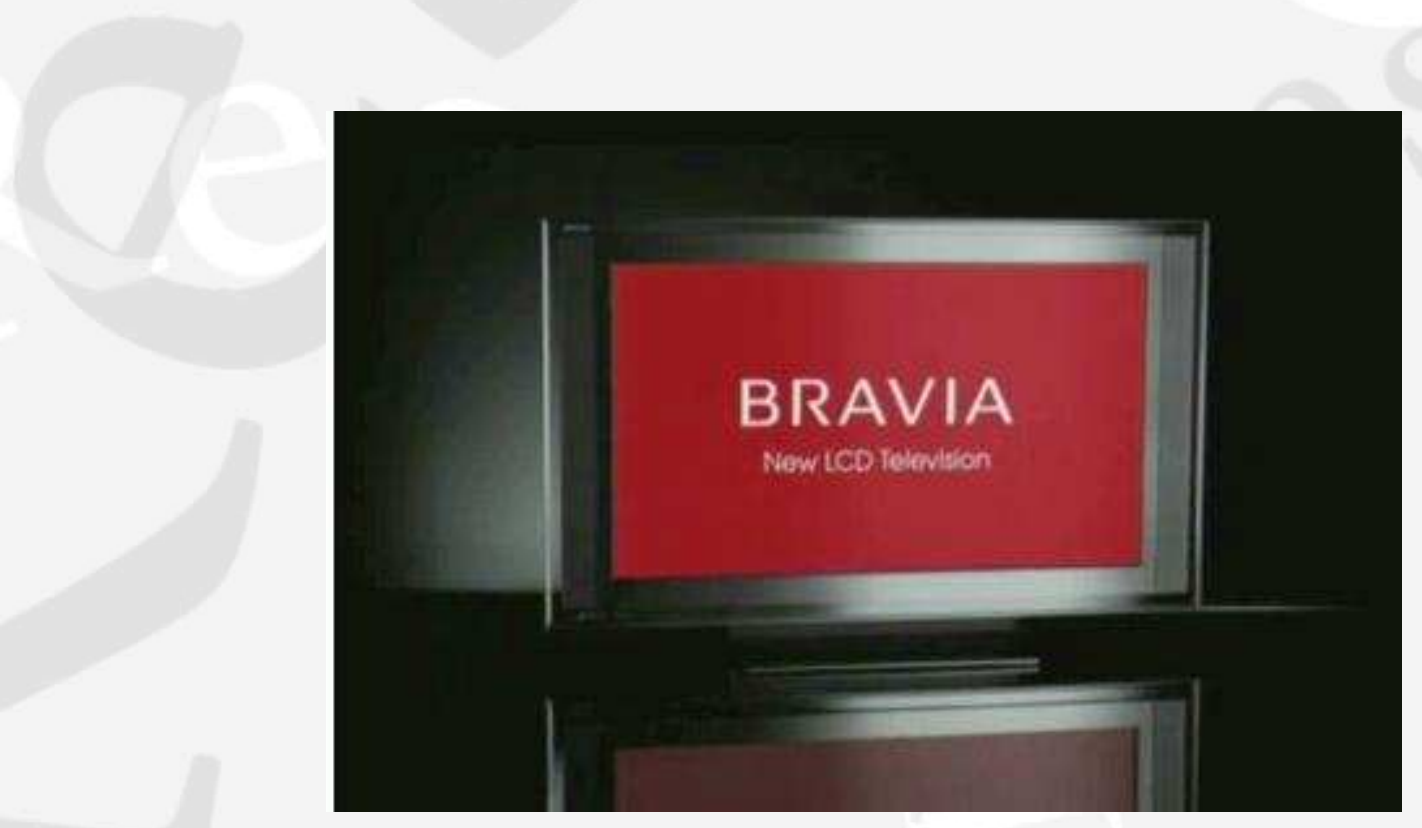

Figura 4: Packshot do filme Play-Doh.

Fonte: Site YouTube, 2009.

Entretenimento é "aquilo que entretém; divertimento, distração, entretimento" (FERREIRA, 2004). Vimos que ele foi usado com inteligência no filme da Sony. Porém, é importante refletir sobre os outros mecanismos utilizados pela marca, aqueles que extrapolaram os limites do filme, construindo uma rede de divulgação que se ramificou pela web, amplificou a publicidade e garantiu o sucesso que presenciamos.

Para Katy Howell, diretora da Immediate Future, empresa on-line de relações públicas, uma companhia pode maximizar seus ativos, construir expectativas, aumentar o conhecimento das pessoas sobre a marca e criar um diálogo que pode ser o começo de um sólido relacionamento entre a marca e o influenciador on-line. A Sony tem utilizado essas estratégias, engajando "consumidores sociais de mídia" com as suas campanhas publicitárias e inspirando altos níveis de "buxixo" sobre a sua marca (HOWELL, 2009). Como definem Ben McConnel e Jackie Huba (2006: 48), o "buxixo" é a profusão de conversas realizadas pessoalmente e pela internet, em salas de bate-papo, quadros de aviso e e-mails encaminhados, sobre um produto ou serviço. É o que se comenta positivamente sobre uma marca, e que contribui para agregar valor à sua imagem.

Play-Doh foi esperado ansiosamente por bloggers, fóruns e outros comunicadores da internet. O 
elemento-chave para se promover essa conversa (entre a marca e os comunicadores) é a necessidade de uma "troca de valor", valor que pode ser entretenimento, informação ou participação, seja em vídeos, fotografias, jogos ou infográficos (HOWELL, 2009). O filme de Sony Bravia, que alimentava expectativas por todos os lados, continha o componente "entretenimento", ao mesmo tempo em que seu lançamento continha o componente "informação", uma informação quente que todos queriam divulgar.

Entre agosto e setembro, os dois meses anteriores ao lançamento, o teaser de Play-Doh foi postado em sites de compartilhamento de vídeo como o YouTube, e teve mais de 200 mil views - após o lançamento, o comercial completo foi postado e atraiu mais de meio milhão de views. Também foi divulgado o vídeo do making of e imagens exclusivas dos coelhos. O site Twitter foi usado para manter os influenciadores atualizados de cada evento. Para aprofundar o relacionamento, a Sony também promoveu um encontro com os influenciadores fora da web, selecionando alguns bloggers para assistirem à filmagem em NY, onde puderam ter contato com os produtores e conseguir conteúdo exclusivo para seus posts. Isso gerou ao final da campanha quase 700 mil menções à marca (HOWELL, 2009).

\section{Conclusão}

Espetacular: palavra que define Play-Doh desde a sua produção, passando pela sua estratégia de divulgação, até a sua repercussão. Entenda-se aqui "espetacular" não como elogio, mas sim com o significado debordiano de "algo grandioso, positivo, indiscutível e inacessível" (DEBORD, 2002: 16). O filme é grandioso nos investimentos, no tempo de duração, na dificuldade de produção, nos mecanismos de propagação. Com tudo isso, difunde valores positivos e indiscutíveis para a marca. A inacessibilidade, por sua vez, está presente na ficção, no mundo mostrado por uma ótica fantasiosa, lúdica. Não se tem acesso àquilo, mas aquilo seduz com a sua surrealidade.

O entretenimento via "produto desmaterializado" surge como um espetáculo dentro do espetáculopublicidade, no qual a mercadoria (mesmo que aparentemente ausente, pois a TV só aparece no final) domina tudo que é vivido. Tal dominação é representada no filme por meio dos coelhos que invadem a cidade. É como se Sony Bravia tomasse Nova Iorque, saindo de suas entranhas e espalhando-se como praga pela sua superfície caótica, que mesmo já lotada de informação encontra espaço para muito mais.

O objetivo da publicidade, mais do que anunciar produtos, sempre foi significar marcas (PEREZ, 2004: 111). É por meio da publicidade, aliada à experiência de uso, que uma marca se constrói. O que vemos, no entanto, é que, para significar uma marca hoje em dia, é preciso inovar nos artifícios. O consumidor não aceita tão bem a publicidade nos seus formatos tradicionais, pois vive em busca do inesperado, em todos os planos da sua vida. Ele quer ser surpreendido, ou ainda, "precisa" ser surpreendido.

Conforme nos mostra Perez (2004: 10) "a marca é uma conexão simbólica e afetiva estabelecida entre uma organização, sua oferta material, intangível e aspiracional e as pessoas para as quais se destina". Ou se faz essa conexão, ou não existe consumo. No caso de Sony, a saída foi o uso do entretenimento no filme, somado à máxima exploração da produção na web, promovendo mais entretenimento. A grande "sacada" da empresa foi contatar as pessoas certas, grupos de interesse que tinham potencial para passar adiante uma informação, uma história, uma novidade. Uniu-se uma superprodução a uma estratégia de divulgação bem arquitetada, e o envolvimento com a marca que disso resulta tem um valor imensurável.

Em longo prazo, isso é mais importante ainda. O que Sony construiu com os três filmes de Sony Bravia e a ligação próxima que estabeleceu com influenciadores - e, por consequiência, com consumidores - é algo que lhe abre espaço para ações futuras, com chances de serem bem-sucedidas.

Assim segue a publicidade contemporânea: tirando a cada dia novos coelhos-idéias da sua cartola 
midiática, para que saltem aos olhos do consumidor. Porque ela, como toda mágica, também perde a graça quando o público descobre o truque.

\section{Bibliografia:}

BAUDRILLARD, Jean. Simulacros e Simulação. Lisboa: Antropos, 1991.

BAUMAN, Zygmunt. Globalização: as conseqüências humanas. Rio de Janeiro: Jorge Zahar Editor, 1999.

DEBORD, Guy. A sociedade do espetáculo. Rio de Janeiro: Contraponto, 2002.

FERREIRA, Aurélio B. de H. Dicionário Eletrônico Aurélio. Versão 5.0. Positivo Informática Ltda, 2004. 1 CD-ROM.

GIRON, Luís Antônio. “Jean Baudrillard: a verdade oblique”. Revista Época. São Paulo: ed. 264, 07 jun 2003.

GODIN, Seth. Marketing Idéia Vírus. Rio de Janeiro: Campus, 2001.

HOWELL, Katy. Stories, passions and actions: how Bravia bunnies inspired the social media conversation. Disponível em: http://www.iabuk.net/en/1/socialmediabraviabunnies.html. Acesso em: 10 abr. 2009

MCCONNEL, Ben; HUBA, Jackie. Buzzmarketing: criando clientes evangelistas. São Paulo: MBooks, 2006.

NOGUEIRA, Pedro P. A reinvenção da publicidade. Monografia de conclusão de curso (Comunicação Social) Universidade Estácio de Sá, Rio de Janeiro, 2004, 58 p.

PEREZ, Clotilde. Signos da marca: expressividade e sensorialidade. São Paulo: Thomson Learning, 2004.

PRODUCT PLACEMENT. Disponível em: http://aprigiofreitas.blogspot.com/2008/12/productplacement_30.html. Acesso em: 23 abr. 2009.

SOUZA, Sandra M. R.; SANTARELLI, Christiane P. G. "Contribuições para uma história da análise da imagem no anúncio publicitário". Intercom - Revista Brasileira de Ciências da Comunicação. São Paulo, v.31, n.1, p. 133-156, jan./jun. 2008.

TELEVISÃO vai continuar por muito tempo. Disponível em:

http://www.abert.org.br/n_clipping_2.cfm?noticia=112021. Acesso em: 21 abr. 2009. 


\section{Créditos das figuras:}

Figura 1: Play-Doh. Cena do filme. Disponível em:

http://media.photobucket.com/image/braviarabbits7/voyatzer/november07/braviarabbits7.jpg. Acesso em 10 mar. 2009.

Figura 2: Play-Doh. Cena do filme. Disponível em: http://www.youtube.com/watch?v=CLUAbkRUvVQ. Acesso em 15 mar. 2009.

Figura 3: SOUZA, Sandra M. R.; SANTARELLI, Christiane P. G. "Contribuições para uma história da análise da imagem no anúncio publicitário”. Intercom - Revista Brasileira de Ciências da Comunicação. São Paulo, v.31, n.1, p. 133-156, jan./jun. 2008.

Figura 4: Play-Doh. Packshot do filme. Disponível em:

http://www.youtube.com/watch?v=CLUAbkRUvVQ. Acesso em 15 mar. 2009.

\section{Mini Currículo :}

Juliana de Assis Furtado é mestre em Comunicação e Práticas de Consumo pela Escola Superior de Propaganda e Marketing (ESPM-SP). Graduada em Publicidade e Propaganda pela Escola de Comunicações e Artes (ECA) da Universidade de São Paulo (USP). 